\title{
Comprehensive methodology for geological risk and multy-risk assessment
}

\section{Комплексна методология за оценка на риска и мултириска от геоложки бедствия}

\section{Antoaneta Frantzova \\ Антоанета Францова}

Geological Institute at Bulgarian Academy of Sciences, Sofia 1113, Bulgaria, Acad. Georgi Bonchev Str., Block 24 , E-mail: afrantzova@gmail.com

\begin{abstract}
This paper presents methodology for geological risk and multy-risk assessment. It is fully in accordance with IEC 31010:2019 and JRC recommendations and has been already applied in the practice. The methodology demonstrating flexibility, adaptability and sustainability within a set of all geological hazards. It is successfully applied to the complex risk assessment of Primorsko municipality.
\end{abstract}

Keywords: risk assessment, multy-risk, geological hazards.

\section{Introduction}

Disaster risk assessment is a qualitative or quantitative approach to determine the nature and extent of disaster risk by analyzing potential hazards and evaluating existing conditions of exposure and vulnerability that together could harm people, property, services, livelihoods and the environment on which they depend (Poljansek et al., 2019).

The terms "risk" expresses the probability of harmful consequences, or expected losses (deaths, injuries, property, livelihoods, economic activity disruption or environment damaged) resulting from interactions between natural or human-induced hazards and vulnerable conditions. The first definition is given by Blaikie et al. (1994):

Risk = function of Hazard and Vulnerability/ Coping capacity (UNISDR, 2002; UNDP, 2004);

Risk $=$ function of Hazard, Exposure and Vulnerability (Poljansek et al., 2019).

\section{Methodology and practice application}

Basic methods and methodologies about the risk and multi-risk assessment are developed by United Nations programs (UN) - ISDR, UNDP; InterAmerican Development Bank and Deutsche Gesellschaft für Technische Zusammenarbeit $\mathrm{GmbH}$
(GTZ); ESPON 3.1.3 Hazards Project (2004); Joint Research Centre (JRC), EC.

The complex approach (based on IADB) include:

$$
\begin{gathered}
\mathrm{H}=\mathrm{w}(\mathrm{H} 1) \times \mathrm{H} 1+\mathrm{w}(\mathrm{H} 2) \times \mathrm{H} 2+\mathrm{w}(\mathrm{H} 3) \mathrm{x} \\
\mathrm{H} 3+\ldots+\mathrm{w}(\mathrm{Hn}) \times \mathrm{Hn} \\
\mathrm{E}=\mathrm{w}(\mathrm{E} 1) \times \mathrm{E} 1+\mathrm{w}(\mathrm{E} 2) \times \mathrm{E} 2+\mathrm{w}(\mathrm{E} 3) \times \mathrm{E} 3+\ldots \\
+\mathrm{w}(\mathrm{En}) \times \mathrm{En} \\
\mathrm{V}=\mathrm{w}(\mathrm{V} 1) \times \mathrm{V} 1+\mathrm{w}(\mathrm{V} 2) \times \mathrm{V} 2+\mathrm{w}(\mathrm{V} 3) \times \\
\mathrm{V} 3+\ldots+\mathrm{w}(\mathrm{Vn}) \times \mathrm{Vn} \\
\mathrm{C}=\mathrm{w}(\mathrm{C} 1) \times \mathrm{C} 1+\mathrm{w}(\mathrm{C} 2) \times \mathrm{C} 2+\mathrm{w}(\mathrm{C} 3) \times \\
\mathrm{C} 3+\ldots+\mathrm{w}(\mathrm{Cn}) \times \mathrm{Cn}
\end{gathered}
$$

where H, E, V and C are the values of the Hazard, Exposure, Vulnerability and Capacity \& Measures, respectively; H1, H2...E1, E2 ...V1, V2 ..C1, C2... refer to the scaled values of the indicators; and wi are the weights. A total sum of the weighting coefficients must be equal to 100 .

The risk profile for the given selected area is expressed as:

$$
\mathrm{R}=(\mathrm{wH}+\mathrm{wE}+\mathrm{wV})-\mathrm{wC}
$$

or

$$
\begin{gathered}
\mathrm{R}=(\mathrm{wH}+\mathrm{wE}+\mathrm{wV}+\mathrm{wRP})-\mathrm{wC} \\
\text { (Frantsova, 2017) }
\end{gathered}
$$


where $\mathrm{H}, \mathrm{E}, \mathrm{V}, \mathrm{C}$ and $\mathrm{PR}$ are the values of the Hazard, Exposure, Vulnerability, Coping Capacity and Risk Perception, respectively; H1, H2... E1, E2... $\mathrm{V} 1, \mathrm{~V} 2 \ldots \mathrm{C} 1, \mathrm{C} 2 \ldots$ refer to the scaled values of the indicators; and wi are the weights (Frantsova, 2017; Frantzova, 2019).

Multi-risk or complex risk is the total risk obtained for all hazardous (disastrous) phenomena peculiar to certain area. The main basis of the multirisk concept is the assumption that most hazards are not hazards per se and triggered by other hazards (UNDP, 2004):

$$
\begin{gathered}
\text { Multy-risk }=\mathrm{w}\left(\text { vRisk }_{\text {floods }}\right)+\mathrm{w}\left(\mathrm{vRisk}_{\text {earthquake }}\right)+\ldots \\
+\mathrm{w}\left(\text { vRisk }_{\mathrm{n} \text {-hazard }}\right)
\end{gathered}
$$

$\mathrm{n}$, number of relevant risks;

$\mathrm{v}_{\mathrm{i}}$, risk levels (selected natural hazards);

$\mathrm{w}_{\mathrm{i}}$, weighing coefficient.

\section{Results}

The developed methodology is fully in line to the IEC 31010:2019 Risk management-Risk assessment techniques and JRC-EC recommendations (Poljansek et al., 2019). It is successfully applied to the complex risk assessment of Primorsko municipality ${ }^{1}$. It includes geological hazards (earthquakes and landslides risks) as well as related to the geology and geomorphology risks (floods, storm surges due to the sedimentation and erosion) and some hydro-meteorological risks due to the temperature variations (drought, cold waves) and storms.

The complex assessment and results obtained show high practical applicability and compatibility. It is based on more than 70 specific indicators describing risk indicators (hazard, exposure, vulnerability, coping capacity, risk perception, etc.). After data calibration and validation, the present methodology is fully compatible with set of geological hazard and disaster.

The final results are presented as risk profiles showing risk levels by five-point scale. The risk level varies from very low to high depending on the different natural phenomena to be assessed, risk indicators relevant to them as well as underlying disaster risk drivers.

To avoid uncertainty linked to the weighing coefficients and averaging the values, related to the multu-risk assessment, coefficient of 1.2 has been introduced, which balances the results, avoid the subjectivity and takes into account mutual reinforcement of the disaster events ongoing at the same

\footnotetext{
1 The project "Complex research, risk assessment and analysis of natural hazards for the territory of Primorsko municipality" is done under signed agreement between CAWRI - BAS and Primorsko municipality (Supervisor of the project - the author).
}

time in the same area. The coefficient is empirically derived and be liable to the future research.

Complete and comprehensive results expressed as risk profiles are presented in the Final project's report.

One of the most important process in the risk assessment requires all hazardous geological processes to be combined into maps (Lakov et al., 2002; Ivanov et al., 2017a, b, 2020; Bruchev, 2018). The geological phenomena having an inherent disastrous potential should be described via the probability of occurrence (experienced hazards and possible hazards) and severity or intensity (experienced hazards and possible hazards).

Many geological phenomena have characteristic which could be derived or/and reinforced from The Global Change Syndromes (described in details in WGBU, 1998; Frantsova, 2017), which increase vulnerability and reduce capacity to cope.

The flexibility of comprehensive methodology allows the final result to be presented either as a risk matrix or risk profiles. It depends on expert judgment, the tasks, issues and scientific problems that need to be solved.

\section{Conclusion}

According to the UNISDR (2004), the risk assessment is the core of the risk management process if the levels of risk are not acceptable, the process of risk management requires different approaches, methods, techniques, tools and strategies to reduce it, depending on the specific characteristics of a particular risk. In the prohibited area, the consequences to be expected are so severe that risk reduction is unconditional. According to these requirements the complex geological risks assessment is applied to Primorsko municipality (South Bulgarian Black Sea coast).

\section{References}

Blaikie, P., T. Cannon, I. Davis, B. Wisner. 1994. At Risk. Natural Hazards, People's Vulnerability and Disasters. London, Routledge, 496 p.; https://doi.org/10.2307/2137699.

Bruchev, I. 2018. Hazardous geological processes on the territory of the Republic of Bulgaria - conditions, factors, geoprotection. - Engineering Geology and Hydrogeology, 32, 57-64 (in Bulgarian with English abstract).

ESPON 1.3.1. Hazards Project. 2004. The Spatial Effects and Management of Natural and Technological Hazards in General and in Relation to Climate Change. Final Report, $100 \mathrm{p}$.

Frantsova, A. 2017. Risk Mapping Methodology and Classification for Environmental Hazards. LAP LAMBERT Academic Publishing, 120 p.; ISBN-10: 3330351160, ISBN13: 978-333035116.

Frantzova, A. 2019. Holistic and multifactorial methodology for natural disaster risk assessment. - Rev. Bulg. Geol. Soc., $80,3,230-232$ 
IEC 31010:2019. Risk Management - Risk Assessment Techniques. Technical Committee, 2 ed., 264 p.

Ivanov, P., B. Berov, N. Dobrev, R. Varbanov, M. Krastanov, G. Frangov. 2017a. Analysis and mapping the landslide hazard in Bulgaria. - In: Advancing Culture of Living with Landslides. Proc. World Landslide Forum 4. Ljubljana, 2, Springer, 1111-1118.

Ivanov, P., B. Berov, N. Dobrev, M. Krastanov, S. Frangov. 2017b. Principles for the assessment and mapping of integrated geological hazard in Bulgaria. - Geologica Balc., 46, 2, 103-109.

Ivanov, P., N. Dobrev, B. Berov, M. Krastanov, R. Nankin. 2020. Assessment of landslide hazard in Bulgaria using GIS. - Proc. Vol. 1, 8th Intern. Confer. on Cartography and GIS. Nessebar, Bulgaria, 297-305.

Lakov, A., S. Stoynev, B. Konstantinov. 2002. Geodynamic hazard and geodynamic risk along the Bulgarian Black Sea coast. - In: Proc. 9th Nat. Mine Surveying Confer. "Analysis, Modelling and Monitoring of Geological Risk in Hazardous Areas”. 17-21 June 2002, Varna, 263-268 (in Bulgarian).
Poljansek, K., A. Casajus Valles, M. Marin Ferrer, A. de Jager, F. Dottori, L. Galbusera, B. Garcia Puerta, G. Giannopoulos, S. Girgin, M. Hernandez Ceballos, G. Iurlaro, V. Karlos, E. Krausmann, M. Larcher, A. Lequarre, M. Theocharidou, M. Montero Prieto, G. Naumann, A. Necci, P. Salamon, M. Sangiorgi, M. Raposo de M. Do N. E. S. de Sotto Mayor, C. Trueba Alonso, G. Tsionis, J. Vogt, M. Wood. 2019. Recommendations for National Risk Assessment for Disaster Risk Management in EU, EUR 29557 EN. Publications Office of the EU, Luxembourg; doi: 10.2760/147842, JRC114650 2021.

UNDP, 2004. Reducing Disaster Risk. A Challenge for Development. United Nations Development Program, Bureau for Crisis and Recovery, Geneva.

UNISDR, 2004. Living with Risk. A Global Review of Disaster Reduction Initiatives. United Nations ISD, Geneva, Switzerland, $429 \mathrm{p}$.

WGBU (German Advisory Council on Global Change). 1998. World in Transition: Strategies for Managing Global Environmental Risks. Annual Report 1998, Springer-Verlag, 359 p.; ISBN 3-540-66743-1. 